\title{
O PRIJEPORIMA ETIČKE POTROŠNJE IZ DRUŠTVENOG RAKURSA
}

\author{
Ivana Brstilo, Ines Krešić i Karla Vučković
}

Studijski odjel sociologije

Hrvatsko katoličko sveučilište

Ilica 242, 10000 Zagreb

Sažetak

e-mail: ivana.brstilo@unicath.hr

Cilj je ovog rada sociološko problematiziranje etičke potrošnje koja je u recentnom društvenom fokusu uslijed niza nesreća u tekstilnim i modnim postrojenjima takozvanih zemalja u razvoju. Uvodno se upućuje na njeno terminološku višeznačnost te se sosvrtom na istraživačke nalaze adresira postojanje heterogenih kategorija etičkih potrošača slijedom čega se formulira teza o složenosti etičke potrošnje u teoriji i praksi. Na primjerima etičkih potrošačkih bojkota pokazujemo kako isti rezultiraju raznovrsnim strategijama tvrtki i korporacija. To etičku potrošnju stavlja u mrežu više interesnih aktera, a ujedno je pozicionira jednom od tržišnih instanci. U radu je poseban fokus na modnoj industriji pri čemu se uočava suprotstavljanje etičke ili "spore" mode dominantnim trendovima "brze" mode, što dovodi u pitanje skoru izvjesnost njene masovne primjene na tekstilnoj i modnoj sceni današnjice. Etička se potrošnja ovim radom promišlja kao ambivalentni fenomen visoke modernosti ili postmodernosti o kojem se može raspravljati na temelju niza radova suvremenih socioloških autora. Zaključno se ukazuje na potrebu dubinskih istraživačkih uvida o ovom rastućem fenomenu iz sociokulturnog konteksta Hrvatske.

Ključne riječi: etička potrošnja, etički potrošači, etički potrošački bojkot, spora moda, postmoderna

\section{UVOD: NESREĆE U TEKSTILNOJ I MODNOJ INDUSTRIJI}

Krajem travnja 2013. u Bangladešu urušila se višekatna građevina Rana Plaza, u kojoj su strane, modne i tekstilne kompanije proizvodile svjetske popularne marke. Pri tome je smrtno stradalo više od tisuću radnika i nekoliko stotina je zadobilo teške ozljede. ${ }^{1}$ Ovaj slučaj, poznat kao nesreća u Rana Plaza-i, ujedno je sinonim stradavanja radnika tekstilne i modne industrije današnjice. ${ }^{2}$ Međutim, ne radi se o izoliranom slučaju. Njemu prethodi

$1 \mathrm{Na}$ mrežnim stranicama nalazimo podatak o 1,134 poginulih radnika i preko 2,500 ozlijeđenih radnika (The fashion revolution, 2016; Clean Clothes Campaign, 2016b).

2 Posebna je pozornost dana ovom slučaju jer su radnici tvornice Rana Plaza (Dhaka, Bangladeš) tvorničkoj upravi prije incidenta dostavili prijave o nizu sigurnosnih propusta na radnom mjestu, da bi se samo dva tjedna nakon prve nesreće slična situacija ponovila, rezultiravši novim ljudskim žrtvama. Više u Clean Clothes Campaign (2015). 
onaj iz rujna 2012. kada je u eksploziji pakistanske tekstilne tvornice Ali Enterprises poginulo više od dvjesto radnika. ${ }^{3}$ Već u studenom iste godine nova nesreća pogađa tekstilne radnike, ovaj put u tvornici Tazreen Fashions ${ }^{4}$ u Bangladešu, kada je u požaru smrtno stradalo više od stotinu radnika i još veći broj ozlijeđenih. U javnost tada izlazi podatak kako se značajan udio tekstilne i modne proizvodnje za internacionalne kompanije kao što su H\&M, Mango, C\&A, KiK, Benetton, nalazi u zemljama poput Bangladeša, Indije, Pakistana, a čiji zaposlenici nemaju regulirana radnička prava pa rade dulje od tjednog prosjeka uz minimalnu naknadu, ${ }^{5}$ nerijetko is toksičnim kemikalijama, u građevinski i sigurnosno neadekvatnim trikotažama, poznatima kao engl. sweatshops.

Neke od navedenih informacija iznijete su u dokumentarnom filmu hrvatskog prijevoda Tko plaća cijenu naše odjeće? iz 2015. koji poziva na reviziju tekstilnog i modnog sustava u cijelosti. ${ }^{6}$ Svojstven glavnini visoko industrijaliziranih zemalja Zapada i Amerike, radi se o sustavu brze mode što je sintagma jeftinih i brzo cirkulirajućih modnih kolekcija koje su s gledišta ekologije i etike neodržive i neetične (Joy i sur., 2012). Prema iznijetim kritikama modna industrija se (re)producira na račun visoke cijene koju plaćaju „životinje, ljudi, lokalni i globalni okoliš, u rasponu od pesticida i kemikalija koje se koriste u proizvodnji tekstila do odbačene odjeće koja brzo puni odlagališta otpada, kao i eksploatacije ljudskih prava povezanih s pitanjima dječjeg rada i sustava trikotaža“" (Winge, 2008:513).

U tom se kontekstu sve veći značaj pridaje osvještavanju potrošačkih izbora koji bi vodili računa o široj društvenoj slici. Pobliže, riječ je o etičkoj potrošnji koju se najavljuje kao novi društveni trend, iako su takva istraživanja uglavnom iz marketinške domene. Izdvojit ćemo istraživanje Etički potrošač (engl. The Ethical Consumer), svojevrsni barometar etičke potrošnje, koje se u Velikoj Britaniji sustavno provodi od 1999. Njime je registriran kontinuiran rast etičke potrošnje do $2015 .{ }^{7}$ Tome u prilog ide i istraživanje provedeno 2015. u SAD-u iz kojeg doznajemo da građani nastoje kupovati etičke proizvode. Točnije, njih $69 \%$ ponekad ili često kupuje proizvode koji se mogu reciklirati, $63 \%$ daje prednost proizvodima koji su manje štetni za okoliš, 58\% kupuje proizvod koji ne zagađuje, 51\% kupuje proizvode kompanija koje doniraju novac u dobrotvorne svrhe, itd. (prema Morgan i sur., 2016:202-203). Navedeni podaci upućuju na činjeni-

3 Više u Clean Clothes Campaign (2016a).

4 Više u Burke i Hammadi (2012).

5 U dokumentarnom filmu The true cost (2015) navodi se da je nadnica tekstilnih radnika oko 2 američka dolara po danu. U Bangladešu tekstilni radnici primaju manju plaću nego zaposlenici iz drugih sektora. Službeno je 2013. vlada propisala povećanje minimalne plaće s 3,000 taka (što je tada iznosilo 28,60 €) na 5,300 taka (tadašnjih 50,32 €). Ne treba izgubiti iz vida ni spolnu strukturu radnika tekstilne industrije. Prema izvještajima inicijative Clean Clothes Campaign, četiri milijuna radnika u Bangladešu zaposleno je u tekstilnoj industriji, a od toga prevladavaju žene, njih 80\%. Više u Clean Clothes Campaign (2013).

6 Originalni engleski naziv filma The true cost (2015) u slobodnom hrvatskom prijevodu može glasiti i puna cijena, a upravo se taj koncept u filmu spominje kao važna inicijativa za povećanje cijena prirodnih resursa do njihovog realnog troškovnika što bi prema nekim projekcijama, nakon kraćeg financijskog izazova za potrošače, potaknulo etičku industriju na duge staze.

7 Više o istraživanju The Ethical Consumer Markets Report 2015 u Triodos Bank i Ethical consumer (2015). 
cu da etička potrošnja napreduje u globalnim okvirima te da se putem potrošnje artikuliraju određeni društveni problemi, a možda i njihova rješenja.

$S$ obzirom da se sociologija u domaćim okvirima nije posebno bavila temom etičke potrošnje, ovaj će se rad upravo tome posvetiti. Konkretno ćemo ukazati na terminologije etičke potrošnje, tipologije etičkih potrošača s naglaskom na primjere bojkota te se pobliže osvrnuti na odnos etičke potrošnje i modnog sustava. Potom ćemo problematizirati bitne stavke etičke potrošnje u domeni (individualne i državne) odgovornosti te ukazati na prijeporne točke u svakodnevici etičkih potrošača. Evidentno je iz ovakve strukture rada da etičkoj potrošnji pristupamo kao ambivalentnoj temi. U osnovi, ovim radom razrađujemo stav da etička potrošnja, usprkos moralizatorskom prizvuku, nije bez kontroverzi.

\section{KONTEKST, TERMINOLOGIJA I OSNOVNE TIPOLOGIJE ETIČKIH POTROŠAČKIH PONAŠANJA}

Suvremeno društvo teži ambivalenciji, a potrošnja je jedno od mjesta ukrštavanja tih tendencija. S jedne strane, potrošnja utjelovljuje konzumeristički modus operandi, a s druge strane zahvaća etički diskurs, propagirajući prava radnika, održivi razvoj te društvenu pravednost. Lipovetsky (2008) upravo analizira suvremeni paradoks u kojem se potrošnja prepoznaje kao uzdanica hiperpotrošačke kulture uznapredovalog kapitalizma, ali i adresat etičkih pitanja. Individualizirana, hedonistička i intimizirana, suvremena potrošnja za sebe, u isti se mah zauzima za druge. „Je li turbo potrošač izgubio svako zanimanje za budućnost? Kako pomiriti tu tezu s porastom 'angažiranih' potrošača, zabrinutih za budućnost planeta koji nastoje dati smisao svojoj kupnji proizvoda utemeljenoj na pravičnosti i solidarnosti? Istina je, što se više potvrđuje imperativ brzine, više se očituju i etička razmatranja, kritički stavovi prema brendovima i 'neodgovornoj' potrošnji. Normativni ideali nipošto ne nestaju, oni su aktivni u novim područjima, posebice u područjima potrošnje" (Lipovetsky, 2008:72). Mada autor ocjenjuje da je etičko tržište još uvijek u povojima, smatra da će se suvremena potrošnja u budućnosti organizirati na korektniji, humaniji, ekološki i socijalno odgovorniji način. (Lipovetsky, 2008:84).

Pobliže, riječ je o etičkoj potrošnji koja je zapadnoj Europi poznata kroz zelene pokrete koji su od kraja šezdesetih i početka sedamdesetih godina 20. stoljeća upozoravali o posljedicama industrijske proizvodnje i masovne potrošnje na okoliš i zdravlje modernog čovjeka, kritizirajući izjednačavanje politike ekonomskog rasta $s$ društvenim prosperitetom i državnom stabilnošću (prema Bocock i sur., 2007:2160; Connolly i Prothero, 2008:118; Muldoon, 2006:2-3). U istim vremenskim i tematskim točkama Berner i Van Tonder (2003) kontekstualiziraju društveni (pre)ustroju vidu postmoderne koju ujedno drže lokusom specifičnih potrošačkih profila. ${ }^{8}$ Navode kako se od sedamdesetih godina

8 Ovdje nam nije namjera ulaziti u opsežne rasprave o postmoderni, već naglasiti njeno tematsko i vremensko koincidiranje s naglascima etičke potrošnje pri čemu smatramo kako se etička potrošnja može razumijevati kao postmoderni fenomen, ali i kao fenomen postmodernosti. 
prošlog stoljeća postmoderna $s$ umjetničkih i arhitekturnih polja proširila na sve sfere društva. Nakon Tema karakterističnih za modernu, poput ekonomskog razvoja, tehnološkog napretka, „posebno utjecaj proizvodnje, mehanizacije i industrijskog kapitalizma", fokus se preusmjerava na nove tehnologije, informacijsku paradigmu, fragmentirane i dinamične institucije, virtualne i umrežene organizacije, kritiku neograničenosti prirodnih resursa te alternativne potrošačke stilove (Berner, Van Tonder, 2003:3). Sukladno tim naglascima autori profiliraju (post)modernog potrošača. Dok moderni potrošač „,vrednuje funkcionalnost i praktičnu vrijednost specifičnog proizvoda i usluge“, postmodernom potrošaču pripisuju „fokusiranost na nematerijalni 'problem' (...) i veću zainteresiranost za simboličnu i kulturnu vrijednost određenog proizvoda ili usluge" (Berner, Van Tonder, 2003:3). Spomenute aspekte Tallontire i suradnici (2001) prepoznaju određujućima za etičku potrošnju i vide je kao suvremeno nasljeđe triju vala potrošačkih pokreta. Prvi val naglašava element informiranog potrošačkog izbora kroz pravovaljano označavanje proizvoda poput njegovih funkcija i sastava. Drugi val ističe pitanja sigurnosti proizvoda i s time povezane odgovornosti kompanija. Treći val kroz potrošnju artikulira građanske i društvene teme, i to u komponentama „(a) dobrobiti životinja, (b) okoliša; i (c) ljudskih prava / radničkih uvjeta te pravedne trgovine“" (prema Tallontire i sur., 2001:7).

Nabrojene komponente prisutne su u većini recentne literature ove tematike. Tako većina autora općim nazivnikom etičke potrošnje drži potrošačke odluke bazirane na dobrobiti okoliša, radnika, životinja te niz, s time povezanih, praksa (prema Tallontire i sur., 2001; Belk i sur., 2005; Caruana, 2007; Littler, 2011). Tako shvaćena etička potrošnja adresira zelene proizvode koji nisu štetni ni za okoliš ni ljudsko zdravlje (npr. organska hrana ili organski pamuk), humane proizvode koji vode računa o dobrobiti životinja (počevši od toga da nisu testirani na životinjama) ili određenim društvenim skupinama (npr. proizvodi u dobrotvorne svrhe namijenjeni oboljelima ili socijalno ugroženim osobama) te varijacije socijalno odgovornih proizvoda proizašlih iz pravedne trgovine (engl. fair trade) temeljene na poštivanju prava radnika i dobavljača, posebno u zemljama u razvoju te očuvanju lokalnih resursa i privreda. Na navedeno se naslanjaju raznovrsne prakse, udružene ili pojedinačne, poput bojkota, potrošačkih inicijativa, etičkog stila života, itd.

Iz navedenog je vidljiva poteškoća definiranja etičke potrošnje. Prema opasci Joergens (2006:261), ne postoji jedinstveni industrijski standard etičke potrošnje, rezultat čega je „raspršena, kompleksna i disparatna" literatura na ovu temu (Papaoikonomou i sur., 2011:198). Littler (2011) se čak pita je li etička potrošnja suviše razgranata da bi bila smislena. Koristi se više terminologija za pojam etičke potrošnje. Određeni se autori referiraju na zelenu potrošnju i zelenog potrošača (Connolly i Prothero, 2008); društveno odgovornu potrošnju (Soneryd i Uggla, 2015); potrošačku etiku ili etičke potrošačke izbore (Belk i sur., 2005); održivu potrošnju i antikonzumerizam (Muldoon, 2006); politički konzumerizam i etički konzumerizam (Dolan, 2005; Micheletti, 2003); itd. Zajedničko je svim ovim terminima orijentacija potrošnje oko „vrijednosti, vrlina i etike“ (Micheletti, 2003:10).

Što se konceptualizacije etičkog potrošačkog ponašanja tiče, u literaturi nanovo detektiramo nekonzistentnost. Osvrnut ćemo se na opći model koji se, sukladno strukama i pristupima, može razrađivati, a prema Tallontire i suradnicima (2001:6) uključuje 
tri koncepta etičkog potrošačkog ponašanja. U prvom tipu izdvajaju negativna etička potrošačka ponašanja povezana $s$ bojkotom pojedinih proizvoda. Drugi tip uključuje pozitivno etičko potrošačko ponašanje manifestirano kupovinom proizvoda s etičkim obilježjima. Treći je tip širi jer nadilazi samu potrošnju i ulazi u sferu životnog stila. Može se predočiti navodima Papaoikonomou i suradnika (2011:209-213) o dobrovoljnoj jednostavnosti ili etičkom pojednostavljivanju koje se odnosi na minimaliziranje osobne potrošnje ili njeno umjereno prakticiranje, ${ }^{9}$ poput ograničavanja impulzivnih potrošačkih odluka ili vođenja računa o njenoj održivoj komponenti, primjerice potrošnjom rabljene (engl. second hand) odjeće. Tome se pridružuju i održive potrošačke navike poput praksi recikliranja, upravljanja otpadom, reduciranja plastične ambalaže, smanjenja energetske potrošnje, korištenja javnog prijevoza, ali i aktivnosti u ekološkim udrugama, potrošačkim kampanjama i slično. Dakle, terminom etičke potrošnje obuhvaćene su iznimno široke i razgranate prakse koje se često međusobno isprepliću, ali su prožete i različitim prijeporima (Littler, 2011).

\section{ETIČKI POTROŠAČKI BOJKOT: U MREŽI POTROŠAČKE MOĆI I KORPORATIVNIH INTERESA}

Bojkot je jedan od učestalijih primjera etičkog potrošačkog ponašanja. Iz njegove temeljne premise o potrošnji kao „sili društvene promjene“ (prema Tallontire i sur., 2001:6) slijede (pre)oblikovanja principa moći na tržištu koje, istaknut će Muldoon (2006), ne funkcionira kao demokracija. Fokus etičkog bojkota je na potrošačima odnosno, njihovoj „aktivnoj demonstraciji načina na koji se moć može koristiti etički u kontekstu potrošnje“ (Shaw i sur., 2005:197). Istraživanje s početka 2015. pokazalo je da približno $20 \%$ populacije Velike Britanije bojkotira određene proizvode ili trgovine iz etičkih razloga, pri čemu prednjače mladi ljudi iz urbanijih sredina. ${ }^{10}$

Sam etički bojkot u praksi nije jednoznačan. Prema Joergens (2006:364) etički potrošači uviđaju da bojkot jedne kompanije povećava dobit neke druge koja ne mora biti etički „čišća“ ali je medijski manje eksponirana čime sustav i dalje suegzistira kroz svoje pritajeno neetičke sastavnice. Općenito je istaknuto u literaturi da mediji imaju značajnu ulogu u osvještavanju javnosti o etičkim temama u potrošnji (Carrigan i Attalla, 2001:569-570; Joergens, 2006:363-370; Connolly i Prothero, 2008:135-136). Za Muldoon (2006) problem je slojevitiji i nisu rijetki granični slučajevi kompanija s, primjerice, izrazitim ekološkim politikama, ali neetičnima po pitanju radničkih prava. Dubiozno je mogu li

9 Uz umjerenu potrošnju, Littler (2011) spominje i antikonzumerizam. Dok se koncept potrošnje općenito odnosi na potrošnju „određenog predmeta, dobra ili usluge, bez obzira na vrstu gospodarskog ili ideološkog konteksta", potonji je ključan za razumijevanje koncepta konzumerizma čija je logika referirana specifikumom potrošačkog kapitalizma (Littler, 2011:2). Slijedom toga, dok umjerena potrošnja zagovara smanjenu potrošnju u postojećem sociokulturnom kontekstu, antikonzumerizam se grupira oko aktivnosti protivnih suvremenoj konzumerističkoj kulturi ili neoliberalnom potrošačkom kapitalizmu (Littler, 2011:2).

10 Više na stranici 7. u dokumentu Ethical Consumer Markets Report 2015 čija je mrežna poveznica navedena u sedmoj bilješci te u popisu literature. 
se takve kompanije definirati neetičnima kada, u nekom drugom segmentu, pristaju uz etična načela (prema Muldoon, 2006:1-6). Zanimljivo je da su istraživanja pokazala da na potrošače više utječe neetička percepcija pojedine kompanije, nego njen proetički imidž (prema Belk i sur., 2005:278). Na tržištu visoke konkurentnosti i drugi tržišni akteri poput dioničara izražavaju osjetljivost za etičke rizike svojih ulaganja (Dolan, 2005:368).

Etički je imidž kapital vrijedan očuvanja, no u praksi su varijabilni ishodi etičkih bojkota koji su usmjereni prema kompanijama. Neke su ih ozbiljno shvatile i uvele politiku korporativne društvene odgovornosti (Smith, 2003) ili su se brendirale kao etički osviještene, druge su odgovorile djelomično, a neke su u potpunosti izbjegle etičkim pritiscima. Jedna od kompanija suočena s kontinuitetom organiziranog bojkota je Nestlé koja se proziva za korištenje dječjeg rada, nepoštivanje radničkih prava i neetičnu trgovinu. $S$ namjerom etičkog prokazivanja ove kompanije, izrasla je čitava civilna internacionalna scena. ${ }^{11}$ Iako je kompanija uvela određena poboljšanja slijedom navedenih kritika, iz etičke perspektive i dalje se uzima za primjer neetičnog modela poslovanja. ${ }^{12}$

Pojedine kompanije ne reagiraju na potrošačke bojkote pokazuje, što slučaj lanca KiK koji je, prema navodima uvodno spomenute inicijative CleanClothesCampaign za poboljšanje uvjeta rada u globalnoj tekstilnoj industriji, jedini korporativni akter povezan sa svim stradanjima tekstilnih i modnih radnika u novije vrijeme. Prema izvještajima iste inicijative, KiK odbija kompenzaciju obiteljima žrtava i donošenje strategija koje bi poboljšale uvjete rada u zemljama poput Indije i Pakistana. ${ }^{13}$ Suprotno tim slučajevima, kompanija H\&M nakon nesreće u zgradi Rana Plaza nastojala je u javnosti prikazati da etički posluje. Zadnjih nekoliko godina provodi politiku korporativne odgovornosti pod geslom održivosti, lansira ekološki osviještene modne kolekcije (tzv. Conscious Exclusive Collection) koje koriste organske materijale (certificirani „bolji“ pamuk), promovira svjetski tjedan recikliranja pri čemu nude mogućnost recikliranja svojim kupcima, itd. ${ }^{14}$ Kompanija je i potpisnik sporazuma o sigurnosnim uvjetima u Bangladešu (u originalu TheAccord on Fireand Building Safety) koji povezuje globalne modne marke, trgovce i sindikate u svrhu zajedničkog unaprjeđenja sigurnosnih i zdravstvenih uvjeta rada u tekstilnoj industriji, ali uz različita stajališta o promoviranom i stvarnom etičkom napretku. ${ }^{15}$

$\mathrm{Na}$ etičkoj crnoj listi često se povlači kompanija L'oreal. Iako se deklarira kao kompanija posvećena okolišu i socijalnim politikama, ${ }^{16}$ na meti je kritika zbog testiranja svojih

11 Udruga „specijalizirana“ za bojkot Nestléa je Baby Milk Action, članica Internacionalne mreže Dječje hrane koja organizira niz (umreženih) bojkota kao što je internacionalni tjedan bez Nestléa (za 2016. održan od 28. listopada do 4. studenoga) s ciljem bojkotiranja njihovog cijelog asortimana - slatkiša kao što je Kit Kat, kave Nescafé, proizvoda kao što je NAN za hranjenje novorođenčadi koji se promoviraju u zamjenu za dojenje, itd. Više u Baby Milk Action. (2014, 2016).

12 Primjerice, nakon prozivki za neetično poslovanje, Nestlé je promovirao model pravedne trgovine kakaa. Radi se samo o fasadi, tvrde zagovornici bojkota, jer je manje od 3\% kakaa ove kompanije proizašlo iz modela pravedne trgovine. Više u Baby Milk Action, 2016.

13 Više u Clean Clothes Campaign (2016). i KiK Textilien und Non-Food GmbH (2015).

14 Više u H\&M Group, 2016.

15 Više u Clean Clothes Campaign et al., 2016.

16 Više u L’Oréal Group, 2016a. 
proizvoda na životinjama (prema Carrigan i Attalla, 2001:568; Arnold, 2009:11). Prema izvještajima organizacija za zaštitu životinja kao što je PETA, kompanija L’oreal pod okriljem zakonskih regulativa pojedinih zemalja provodi testiranja na životinjama. ${ }^{17} \mathrm{Na}$ svojim službenim stranicama L'oreal brani vlastiti etički profil navodima da su takva testiranja tek rijetke iznimke, ${ }^{18}$ ali zagovaratelji prava životinja ih vide kao etičke mrlje kojima se obmanjuje javnost i prepreku u informiranju etičkog djelovanja potrošača ${ }^{19}$ (Carrigan i Attalla, 2001).

Evidentno je iz izdvojenih primjera da se $s$ etičkim bojkotom javlja korporativno opiranje i razna manevriranja, tako da etičke bojkote možemo sagledati u interesnoj mreži uključenih strana i suproizvedenih (re)akcija. S time se može povezati Castellsov (2000) koncept moći koja je, kako je primijećeno u predgovoru njegove kultne knjige Uspon umreženog društva, otvoreno polje koje se sve više „pomiče prema kulturnoj sferi, prema mjestima gdje se informacije vezuju za uvjerenja i obrasce ponašanja ljudi i time oblikuju njihovo iskustvo i spremnost na akciju" (Katunarić, prema Castells, 2000:26). Uz moć on veže tri oblika i izvorišta identiteta. To je legitimirajući identitet pod kontrolom interesa upravljačkih društvenih institucija; identitet otpora predstavljen subjektima koji se opiru logici dominacije kao izvoru vlastite subordiniranosti; projektni identitet aktera koji žele putem novog identiteta promijeniti vlastiti društveni položaj te provesti transformaciju društvene strukture (Castells, 2002:17-22). Računajući na dinamiku identiteta u raznim povijesnim kontekstima, Castells (2002) identitet otpora drži najvažnijim za društvo današnjice. U njemu se uzajamno obraćaju isključeni subjekti, dominante institucije i ideologije (Castells, 2002:19), tematski preneseni u etičke bojkotne inicijative, globalne kompanije te njihove tržišne interese. Zaključak Spaargaren i Mol (2008:351) da akterima ostaju protestne akcije upravo iz pozicije identiteta otpora naspram neoliberalnih ideologija vraća nas na pitanje izvorišta moći u kontekstu ovog rada. Ono se, smatramo, uvelike generira u potrošnji i robi. Onoj istoj koja po Dolan, konzumirala se ili ne, postaje „totem odnosa moći između potrošača i proizvođača“ te mjesto novih društvenih previranja (prema Connolly i Prothero, 2008:130).

\section{IZ DIMENZIJE SVAKODNEVICE ETIČKIH POTROŠAČA: IZMEĐU NESUSTAVNIH PRAKSA I KOEGZISTIRAJUĆIH VRIJEDNOSTI}

Dok se na primjeru etičkih potrošačkih bojkota ulazi u sfere zakulisne moći na razini korporacija i tržišnog sustava, u ovom pasusu posvetit ćemo se dimenziji svakodnevice etičkih potrošača.

Iz rijetkih empirijskih uvida zahvaljujući Connolly i Prothero (2008) doznajemo da se etički potrošači trude svakodnevno živjeti po etičkim obrascima pa koriste prirodno

17 Više u PETA, 2016.

18 Više u L’Oréal Group, 2016b.

19 Više u Cruelty-Free Kitty, 2017. 
gnojivo (kompost), prakticiraju recikliranje, bave se organskim uzgojem, kupuju u trgovinama rabljene odjeće, nabavljaju potrepštine iz zelenih trgovina ili s lokalnih farmi. Iz ovog je vidljivo da se korpus njihovih etičkih praksa provlači kroz različite domene života. Međutim, istodobno su njihove prakse sone strane etičnosti jer kupuju u velikim potrošačkim centrima kojima u načelu pridaju negativne karakteristike, posjeduju automobil i redovito koriste zračni prijevoz, financiraju dječje odlaske u lance brze prehrane kojima se osobno protive, znaju i sami konzumirati brzu (engl. fast) hranu, a neki kupuju proizvode kompanija koje se kritiziraju zbog etičkih načela (Connolly i Prothero, 2008:127-128).

Izdvojene kontradikcije koje prožimaju svakodnevicu etičkih potrošača po nekima dovodi u pitanje smisao njihove etičke pozicije. Takve kontradikcije po Spaargaren (2003:689) zorno ilustrira slika motorista na Harley - Davidsonu koji je, usprkos pozamašnoj produkciji $\mathrm{CO}_{2}$ svog vozila, aktivni član lokalne ekološke udruge. Dok će neki takvo ponašanje pripisati modelu kompenzacije (Spaargaren, 2003) ili pregovaranja s društvenom okolinom (Connolly i Prothero, 2008), preporuka pojedinih autora je da se etički potrošači sagledaju u širini svojih identiteta (prema Tallontire i sur., 2001; Bocock i sur., 2007). Primjerice, studija Newholm ustanovila je da profili etičkih potrošača variraju: od onih koji su apsolutno predani etičkim načelima i žele ih zaokružiti holističkom filozofijom življenja koja će ih jasno odvojiti od konzumerističkog mentaliteta, preko profila etičkih potrošača koji prakticiraju selektivnu etičku potrošnju koja ne dovodi u pitanje potrošačko društvo kao takvo, već djeluje etički prema procijenjenoj potrebi (prema Tallontire i sur., 2001:19-20). Iz perspektive organizacija za pravednu trgovinu izdvojena su pak tri stila etičkih potrošača. Prvi su aktivisti kao redoviti i posvećeni etički potrošači; redoviti etički potrošači koji žele znati više o proizvodima; povremeni polu-etički potrošači koji kupuju etičke proizvode, ali trebaju dodatne poticaje za sustavniju praksu (u vidu bolje dostupnosti proizvoda, atraktivnosti i slično) (prema Tallontire i sur., 2001:16). Navedeno upućuje da etički potrošači nisu homogena kategorija pa se manifestne (ne)etičke prakse trebaju promatrati sukladno njihovim različitim profilima i stilovima.

Važan je i empirijski nalaz da potrošači općenito nisu jednako zainteresirani za sve etičke teme. Tako istraživanje Carrigan i Attalla (2001) evidentira parcijalni interes potrošača za "pojedine vrste društvenih tema“ i pokazuju da postoji „lista etičkih prioriteta“ na kojoj su prava životinja važnija od prava radnika ili budućnosti prašuma ${ }^{20}$ (Carrigan i Attalla, 2001:569).

Također kod potrošača postoje razilaženja oko interpretiranja (ne)etičkog poslovanja. Dok neki dječji rad najoštrije osuđuju, drugi napominju da isti problem treba kontekstualizirati. Taj dio javnosti smatra da je dijete zaštićenije u tvornici nego na ulici (Joergens, 2006:366). Ovim se iz potrošačke perspektive zagovara redefiniranje(ne)etičkog

20 Tallontire i suradnici (2001:10) pozivaju se na rezultate izvještaja Mintel prema kojem 50\% ispitanika ne bi kupilo proizvod testiran na životinjama, dok njih $21 \%$ ne bi kupilo proizvod iz tvorničkih farma. Uviđamo, dakle, da potrošači nisu jednako senzibilizirani za sve etičke teme. 
poslovanja prema ekonomskim i gospodarskim prosjecima pojedinih država. Pojedinim potrošačima je upitno problematizirati i visinu plaće radnika u zemljama proizvodnje jer je drže prilagođenom konkretnoj životnoj sredini (prema Carrigan i Attalla, 2001:569). I u drugim istraživanjima je zabilježeno etičko racionaliziranje potrošača. Jedno od njih je da „zapadne kompanije omogućavaju poslove radnicima zemalja u razvoju pa se čini razumljivo da se zapadne kompanije prilagode lokalnim uvjetima" (Joergens, 2006:366). Iz navedenog je razvidno da ne postoji jednostrano razumijevanje ni podrška etičkog poslovanja, što dodatno poentira kompleksnost same etičke potrošnje. Slijedom saznanja o nesustavnim etičkim praksama potrošača u svakodnevici, neki dovode u pitanje i motive etičkih potrošača. Tvrdnjom da ih manje zanima socijalna dobrobit, a više vlastita biografija, smatraju da im „etičke potrošačke prakse služe kao način konstruiranja etičkog sebstva i razlikovanja njih samih od drugih potrošača" (Papaoikonomou i sur., 2011:209). Iz ovih navoda etička potrošnja se može iščitati kao samousmjerena briga za vlastito zdravlje i tijelo, a tek sekundarno kao iskaz brige za društveno dobro (prema Connolly i Prothero, 2008:135; Joergens, 2006).

Međutim, pojedina empirijska saznanja nam ne daju potkrijepe za dihotomno rezoniranje. Među takvima je istraživanje Shaw i suradnika (2005) o odnosu vrijednosti i etičke potrošnje u domeni hrane. Suprotno stavovima o etičkoj potrošnji kao samointeresnoj praksi, autori navode da je vrijednost univerzalizma s naglaskom na jednakost (jednake prilike za sve), socijalnu pravdu (ispravljanje nepravde, briga za nemoćne) i dobrobit okoliša (očuvanje prirode) značajno prisutna kod etičkih potrošača prilikom odluka o kupovini hrane. Potvrđena je značajnost i drugih vrijednosti u kupovini hrane, a među njima je najizraženija vrijednost zdravlja. Ne radi se o strahu od bolesti, već etički potrošači ciljano kupuju zdravu hranu kako bi ostali zdravi. Pažljivim odabirom proizvoda koje u sebe unose pokazuju angažiranu zabrinutost za vlastitu dobrobit, ali i povezuju vrijednost zdravlja $s$,organskim proizvodima, dobrobiti životinja i genetski nemodificiranom hranom" (Shaw i sur., 2005:192). Ostale vrijednosti koje su se pokazale značajnima su vrijednost slobode (sloboda djelovanja i mišljenja), obiteljske sigurnosti (sigurnost bližnjih), pomaganja (rad za dobrobit drugih), odgovornosti (pouzdanost) (Shaw i sur., 2005). I druga srodna istraživanja upućuju na koegzistenciju vrijednosti kod etičkih potrošača. Upravo se na primjeru organskih proizvoda pokazuje da su razlozi njihove kupovine „brojni i variraju“ - kupuju se zbog izbjegavanja pesticida, uvjerenja da su benevolentniji za okoliš, zabrinutosti oko uzgoja životinja, podržavanja lokalnih farmera, brige oko kravljeg ludila, boljeg okusa (prema Tallontire i sur., 2001:14). Ove nalaze možemo povezati sa stavom Bocock i suradnika koji tvrde kako etička potrošnja nije „isključivo filantropska i praktična vježba“ (2007:2160), već se, kako Littler tvrdi (2011:1), može razumjeti u matrici kontradiktornosti Prema navedenom, zaključujemo da je etička potrošnja vrijednosno polifona praksa, koja se, usprkos usmjerenosti na vlastitu dobrobit i nesustavnim etičkim ponašanjima, ne može odvojiti od konteksta društvene dobrobiti.

Kompleksne vrijednosti, stavove i ciljeve u podlozi etičkih potrošačkih izbora, McEachern i Carrigan (2010) drže čimbenicima njene nepredvidljivosti i nesustavnosti. Iz 
navedenih aspekata nazire se postmoderni kontekst koji je po nama ključ razumijevanja etičke potrošnje. Na to nas dodatno upućuju empirijska saznanja o stalnoj anksioznosti, nesigurnosti i samopreispitivanjima etičkih potrošača oko vlastitih izbora i ponašanja u svakodnevnoj potrošnji (Connolly i Prothero, 2008:137; Tallontire i sur., 2001:20-21). Nadalje, saznanja pokazuju da etički potrošači osjećaju odgovornost za vlastite prakse i nastoje ih etički (pre)usmjeravati, ali pri tome identificiraju različite poteškoće. „Poteškoća je u osjećaju individualne (ne)moći popraćenom dodatnom nesigurnosti (...) što treba činiti. Na izvjestan način pojedinci imaju osjećaj da znaju da nešto trebaju i mogu učiniti, ali ne znaju kako. Ne čudi, stoga, da se usporedo s ovim pokušajima donošenja ispravnih odluka pojavljuju osjećaji krivnje, ambivalencije, kompromisa i nedosljednosti u adresiranju pitanja zaštite okoliša na osobnoj razini“"(Connolly i Prothero, 2008:133). Škripac u kojem se nalaze etički potrošači Bauman (2009) pripisuje se postmoderni inherentnom nepostojanju jednoobraznih pravila za etički neprijepornu praksu. Zapravo je sam pravovaljani model istine iscrpljen. „Umjesto toga postoje mnoge agencije i mnogi etički standardi čija prisutnost baca pojedinca u stanje moralne nesigurnosti iz kojeg nema potpuno zadovoljavajućeg i jednostavnog izlaza“" (Bauman, 2009:43). Razne dileme i konstantna višesmislenost dobrog rješenja po autoru predstavljaju žanr budućnosti (Bauman, 2009:43-44). Etičke potrošačke prakse iz tog ugla egzistiraju u mreži ispreplitanih motiva što nas upućuje na njihov relacijski diskurs. Tim slijedom i nije poanta brinu li se etički potrošači za svoje tijelo i stil ili im je više stalo do društvene dobrobiti, jer suvremena etika ne funkcionira po onom što Bauman (2009:12) detektira ili-ili modelom.

Ulogu koju etička potrošnja zauzima u životima etičkih potrošača, naročito nakon što se globalni problemi svedu na razinu vlastitih nastojanja, prema Connolly i Prothero (2008:142) zrcale leće refleksivne modernizacije. S tim se osvrćemo na Giddensa (1991) koji tvrdi da tekuća, refleksivna modernost (pre)oblikuje ljudsku svakodnevicu i spaja i globalno i lokalno u jedinstveni osobni projekt. „Modernost je post-tradicionalni poredak u kojem se na pitanje Kako ću živjeti? mora odgovarati dan po dan i donositi odluke o tome kako ćemo se ponašati, što ćemo obući i što ćemo jesti“ (Giddens, 1991:14). Potkopavajući sigurnost znanja te odbacujući zaključene istine, refleksivna modernost revidira i preispituje razne odluke (Giddens, 1991:21). Osobni izbor nikad nije bio osobniji u smislu da se u društvu visoke modernosti propagira individualno preuzimanje kontrole nad vlastitim životom, ali se $s$ druge strane ne nude sigurni izvori znanja iz kojih bi se takve odluke mogle usvajati i utemeljiti. Sumnja, dvosmislenost i nesigurnost postaju odlike suvremenog potrošača (prema Berner i Van Tonder, 2008:3). U stanju intenzivne (visoke) modernosti, centralno se pitanje po Giddensu (1991) vrti oko (ne)ispravnog načina življenja zahvaćajući mentalne procese (razmišljam li ispravno?), prostor prakse (djelujem li ispravno?) te domenu tijela. „Refleksivnost sebstva se širi na tijelo, gdje je tijelo (...) dio sistema akcije, radije nego pasivni objekt" (Giddens, 2001:77) pri čemu se nadgledaju tjelesni procesi zasebno, u cjelini, i u odnosu na okolinu. Tjelesna se osviještenost uz stalno (samo)motrenje po Giddensu (1991) ispoljava vježbanjem i dijetama. Isti diskurs je po nama prenosiv i na etičku potrošnju. Jednako kao što je di- 
jeta razložna na odluke o tome što (točno) jesti i piti, tako je i etička potrošnja saglediva kroz ono što unosimo u sebe (npr. kroz organsku i zelenu potrošnju hrane) i / li ono što stavljamo na sebe (npr. kroz modu proizašlu iz pravedne trgovine). Tako promišljena, etička potrošnja reflektira sebstvo kojem je tijelo referentna i aplikativna točka projekta u nastajanju što je otvara različitim kombinacijama u teoriji i praksi.

\section{ETIČKA POTROŠNJA U PITANJU INDIVIDUALNE I DRŽAVNE ODGOVORNOSTI}

Društveni, ekološki i gospodarski problemi nadišli su vremenske i prostorne granice pojedinih država te ih se može sagledati kao globalne fenomene koji traže zajednička rješenja i povezane pristupe. Na određeni način to i jest smisao globalizacije prema Giddensu (1991:21-22) shvaćene kao nadnacionalne interakcije u prostornoj i vremenskoj dijalektici. Usprkos takvim naglascima, sve se veća uloga u rješavanju globalnih fenomena pridaje pojedincu. Kroz stav da je „svaki pojedinac dužan biti razborit, odgovoran za vlastitu sudbinu" (prema Soneryd i Uggla, 2015:917), krupni društveni problemi podvode na razinu odgovornosti i djelovanjem pojedinca. Po Muldoon (2006) upravo je individualizacija odgovornosti sporna stavka etičke potrošnje. Njome se, doduše, osvjetljavaju mogućnosti pojedinačnog djelovanja (Soneryd i Uggla, 2015; Micheletti, 2003), ali se zamagljuje prostor (su)djelovanja korporativnih struktura u razini država ili vla$\mathrm{da}^{21}$ te strukturalnih ograničenja u čimbenicima klase, etniciteta, rase, spola. ${ }^{22}$ Muldoon (2006) sam kapitalistički sustav smatra nesklonim etičkoj potrošnji, počevši od manjkavih i nepouzdanih informacija što je u više analiza istaknuto preprekom etičnom djelovanju (Joergens, 2006; Carrigan i Attalla, 2001; Tallontire i sur., 2001). Suprotno tome određena interkulturna istraživanja ukazuju na potrebu tržišnog zaokreta, „umjesto da potrošači usmjeravaju poslovanje prema etičkom ponašanju, možda je potrebno obrnuto" (Belk i sur., 2005:283).

Iako se etičkom potrošnjom preispituju i, kako je pokazano u primjeru etičkog bojkota, nastoje mijenjati neetični tržišni modeli rada i poslovanja, pripisuje joj se problematična kompatibilnost $s$ tržišnim strukturama. Po Dolan (2005:383) etički uzlet u potrošnji konsolidirao je samu potrošnju u neprikosnoveno izvorište suvremene moći. To znači da se usprkos etičkim strujanjima kanali moći nisu bitno promijenili, nego etički prebojili. U kontekstu toga shvatljiv je termin (engl.) greenwashing kojim se opisuju zeleni progra-

21 Prema Muldoon (2006) problem je u nerazmjeru odnosa moći u kojima gdje država i korporacije apstrahiraju efekt na pojedinca.

22 Soneryd i Uggla (2015) primjećuju da agenda individualne odgovornosti u etičkoj potrošnji na ljude gleda kao transformacijski na refleksivna ili tradicionalna bića, naglašavajući prolaznost kolektivnih akcija i angažmana, a ne uzimajući u obzir strukturalna ograničenja kao što je obrazovanje, socioekonomski status, etnicitet, rasa i slično. Vezano uz to su nalazi kako se etička potrošnja teško mjeri tradicionalnim demografskim varijablama, no u tom se slučaju žene i stariji potrošači pokazuju osvještenijima (prema Bocock i sur., 2007). Za potvrdu izdvajamo istraživanje iz 2010. prema kojemu se $64 \%$ žena izjašnjava etički osviještenima kao i više od 70\% osoba starijih od 60. u Kanadi (Coletto, 2011). 
mi kompanija koji su najčešće kozmetički u smislu da ispunjavaju minimum ekoloških standarda (Muldoon, 2006). Jedan od takvih primjera je vezan uz korporaciju WalMart koja se promovira zelenom kompanijom, mada tek dvije njihove podružnice na cijelom području Sjedinjenih Američkih Država zadovoljavaju takve kriterije. Intrigantan je i slučaj kompanije Home Depot koja je u Americi „ozelenila“ više tisuća svojih proizvodnih linija tako da su plastične drške kistova označili ekološkima jer nisu drveni, dok su drvene drške kistova također proglasili „boljima za planet“ s obzirom da nisu plastični (Littler, 2011:4). Upravo na primjeru zelene potrošnje Muldoon (2006) objašnjava kako ista ne dovodi u pitanje kapitalističku logiku rasta od čije kritike polazi. Odatle i situacija da zelena industrija izrasta u ,potrošačko-proizvođačku industriju rasta“ (Muldoon, 2006:5), a s njome raste i zelena potrošnja te kompanije s predznakom održivosti (prema Dolan, 2005:367; Connolly i Prothero, 2008:130).Tu situaciju zorno ocrtava Arnold kako je etika ,jedna od najmoćnijih stvari koju poslovanje može iskoristiti“ (2009:10). Prema Muldoon (2005), to se može i očekivati jer živimo u potrošačkom društvu koje različite vrijednosti i prakse podvrgava svojstvenim interesima. $U$ ovom tonu etička potrošnja se može uzeti za reprezent tržišne savitljivosti koja na račun novih društvenih rizika gradi unosnu industriju i profitabilno etičko tržište.

Slijedom Becka (2001), tekući rizici poput krize (ne)održivosti postaju politička i ekonomska okretišta suvremenog svijeta. Stoga je opravdano govoriti o komercijalizaciji rizika, tematici koju Beck (2001) urezuje u glavne točke (društva) rizika, a kojom razjašnjava da su rizici u kasnoj moderni okom nevidljivi, ali nesumnjivo razorni. Mada distribucija rizika neke skupine čini izloženijima ili ugroženijima, globalni rizici poput istrebljenja prirodnih resursa ili klimatskih promjena ne prate klasnu hijerarhiju, već zarezuju globalno. Po tom „efektu bumeranga“ rizik pogađa sve društvene aktere, uključujući one koji njima manipuliraju. „Istovremeno, rizici proizvode nove internacionalne nejednakosti, s jedne strane, između Trećeg svijeta i industrijskih država, a s druge, između samih industrijskih država" (Beck, 2001:36). Jednom definirani, rizici postaju politički, ali i ispolitizirani, a istim tragom i komercijalizirani u domenu visoke profitabilnosti (engl. big business risks). Rizici u osnovi održavaju puls kapitalizma i postaju predmet interesa krupnog kapitala i visoke politike (Beck, 2001:36-37).

S ovim se vraćamo na pitanje odgovornosti. Prema Muldoon (2006) nužno je osvijetliti granice mogućnosti iz rakursa pojedinaca te uključiti državu u proces etičke suodgovornosti. Različiti su načini na koji država može i mora pogodovati etičkoj klimi, počevši od reguliranja etičkih obveza korporacija i kompanija. ${ }^{23}$ Nadalje, autorica smatra da bi obveza implementiranja ekoloških programa usmjerila kompanije prema većoj politici održivosti, ${ }^{24}$ kao i da bi uvođenje službenih ekoloških oznaka proizvoda koji manje op-

23 Iako se često stavlja naglasak na kompanije i korporacije zbog njihove tržišne vidljivosti, često i u globalnim razmjerima, etički se standard ne tiče samo velikih tržišnih igrača, već se treba uračunati i provesti i kod malih tvrtka i obrtnika, uz oprez da ih ne unazadi (Tallontire i sur., 2001:30).

24 Za primjer se uzima slučaj Njemačke gdje je država kompanijama propisala obvezu od čak $72 \%$ proizvodnje boca koje se mogu iznova puniti ili slučaj Danske gdje je taj postotak čak $98 \%$ (prema Muldoon, 2006:8) 
terećuju okoliš doprinijelo transparentnijem tržišnom sustavu koji bi pogodovao ovom vidu potrošnje. Proaktivni pristup vlade i službenih tijela vlasti ima moć integriranja etike u tržišne odnose i širu potrošnju, aludira Muldoon (2006:8-9). I drugi autori vide budućnost etičke potrošnje u državnom propagiranju, bilo putem prikladnih zakona, državnih fondova za pouzdano informiranje o proizvodima, smjernica tvrtkama za etičniji pristup, „posebno kada se radi u zemljama u razvoju“, fiskalnim poticajima dobrih praksa i raznih inicijativa za standardizaciju socijalnih i okolišnih praksa, i slično (Tallontire i sur., 2001:27). „Postoji značajan potencijal vlade u podržavanju nastojanja tvrtki za većom odgovornošću i na taj način povećanju potrošnje proizvoda s etičkim karakteristikama" (Tallontire i sur., 2001:27). Međutim, u globaliziranom svijetu pitanje uloge države je sve neizvjesnije. Ako gledamo iz Castellsova (2000) kuta, vrijeme države nije prošlo, ali je kontekstualiziran informacionalnom paradigmom $s$ kojom se nekoć čvrsta nacionalna i ekonomska uporišta prebacuju na sustav bezvremenog vremena i prostora tokova. U mrežnoj konstelaciji države nisu ekskluzivni autoriteti, već jedni od čvorišta moći čija logika korelira s onom globalnog kapitala. Prema mišljenju Spaargaren i Mol države „postaju sve manje i manje sposobne svrhovito djelovati to jest, utjecati i oblikovati rezultate globalnih procesa u prostoru tokova" (2008:351). Slične teze zastupa i Bauman koji najavljuje povlačenje moći iz službene sfere politike is mjesta države u sferu individualizma i slobode izbora (prema Lekakis, 2013:49). Za Baumana (2009) je odlika tekuće, postmoderne ere, gubitak kapaciteta, želje i sposobnosti države za svekolikim formama vodstva. Dok je moderna država upravljala individualnim i kolektivnim egzistencijama, suvereno vladajući ekonomskim, kulturnim i vojnim resursima, postmoderna država gubi uporište na istom „tronošcu“. „Obilno diskutirana, globalizacija ekonomije i kulturalnih zaliha, zajedno $s$ defenzivnom nedovoljnošću svake političke jedinice uzete posebno, donosi moderne države 'kakve poznajemo' (...) $\mathrm{Na}$ gotovo svakom polju života monopol moći nad svakim pojedinim stanovnikom ispada iz oslabljene ruke države" (Bauman, 2009:174). Ako se pokaže da je razvodom državne politike i građanstva nepovratno ispražnjeno polje društvenosti (Bauman, 2009:176), sa sobom bi moglo povući dodatno zaoštravanje paradigme individualnosti. $U$ toj interpretaciji i pitanje nadležnosti etičke potrošnje bi moglo (iz)visiti između potreba za kulturnim promjenama daleko iznad mogućnosti pojedinaca (Winge, 2008) i stanja državne (ne)moći (Bauman, 2009).

\section{ETIČKA POTROŠNJA I MODNI SISTEM: IZMEĐU BRZE I SPORE MODE}

Zadnjih je godina primijećena popularizacija etičke mode pa su neki u modnom žargonu najavili da je zelena nova crna (prema Winge, 2008:511). Iako se etička i modna suradnja intenzivirala uslijed uvodno spomenutih nesreća, njeni noviji korijeni prate modne manifestacije poput one iz 2001. kada je na Novom Zelandu organizirana međunarodna promocija ekološke, reciklažne mode pod nazivom Trash to Fashion. U modnoj prijestolnici Parizu, 2004. organizirana je prestižna etička modna revija (engl. 
Ethical fashion Show), a slični sadržaji narednih se godina pokreću diljem Sjedinjenih Američkih Država, Kanade, Brazila, itd. (Winge, 2008:511-517).

U globalnoj popularizaciji etičke mode veliku ulogu odigrali su prominentni dizajneri, mahom vlasnici ekskluzivnih modnih marki, ${ }^{25}$ trendovskim dekonstrukcijama eko-haljine (engl. eco-dress). Nekoć stereotipizirana supkulturom hipija i konzumerističkim subverzivom, pod eko-haljinom misli se na odjeću, obuću i razne modne dodatke koji su dizajnirani, proizvedeni, transportirani, distribuirani i slično, metodama koje uzimaju u obzir zaštitu okoliša, ljudska i životinjska prava (Winge, 2008:511-512). Iz toga proizlazi shvaćanje etičke mode kao osviještene koja koristi prirodne, biorazgradive, održive materijale za dugotrajnu upotrebu, a koji najmanje oštećuje okoliš i razvijaju se u sustavu senzibilnom za prava radnika i dobrobit životinja (Joergens, 2006:361; Gwozdz i sur., 2013:14).

Usprkos optimističnim najavama o sve većoj popularnosti etičke mode, ona još uvijek nije masovni fenomen. ${ }^{26} \mathrm{Za}$ razliku od nekih drugih aspekata etičke potrošnje poput hrane, spomenimo i kako je upravo kupovina etičke odjeće doživjela pad u razdoblju 2013. i 2014. ${ }^{27}$ Štoviše, Winge (2008) primjećuje svojevrsni elitizam kod etičke modne klijentele te (po)modnih aktivista iz reda slavnih i utjecajnih (engl. celebrity). Nerijetki su i slučajevi kratkoročnih preorijentacija modnih kompanija na etički program iz razloga što se isti nisu pokazali toliko unosnima kao brza moda (Winge, 2008:515-516). Potonji koncept zahvaća povoljne modne linije koje se na tržištu izmjenjuju po trendovskom ključu. Uslijed ograničenih količina i kratkoročne vremenske dostupnosti takve modne ponude, karakterizira brza reakcija potrošača. Ponekad se radi o robi koja se tjedno distribuira (prema Joy i sur., 2012:275). Za ilustraciju, nekoć je kolekcijama s modnih pista trebalo oko šest mjeseci da dođu do potrošača, a danas se isti rok realizira u tjednima, najčešće izravno iz modnih studija. „Brza moda napreduje u brzim ciklusima: brza izrada prototipa, male količine kombinirane s velikim varijacijama, učinkovitiji prijevoz i dostava" kao i roba već spremna za korištenje (prema Joy i sur., 2012:275). Posebno se to odnosi na modne marke kao što su H\&M, Mango i Zara čiji robni asortiman ne funkcionira sezonski, već u konstantnom priljevu među-kolekcija, pret-kolekcija, limitiranih kolekcija i tako dalje. U toj dinamici marke brze mode održavaju konstantan interes potrošača što, primijetit će Joy sa suradnicima (2012:275), rezultira postmodernom formom masovnog modnog ekskluziviteta.

\footnotetext{
25 Radi se o dizajnerima kao što su Oscar de la Renta, Giorgio Armani, Stella McCartney, Todd Oldham i drugi (Winge, 2008:513)

26 Ovdje se želimo osvrnuti na opasku Tallontire i suradnika (2001) kako se, usprkos entuzijastičnim najavama rasta etičke potrošnje, ista više zagovara, negoli prakticira. No, u vezi s tim, bitno je uzeti u obzir datiranje članka. Ažurirane brojke etičke potrošnje su uočljive u grafičkom prikazu na stranici 3 dokumenta The Ethical Consumer Markets Report 2015. čija je mrežna poveznica navedena u sedmoj bilješci te u popisu literature. Iz istog se dokumenta može zaključiti kako etička potrošnja bilježi kontinuirani trend rasta, no još je uvijek riječ o skromnim brojkama.

27 Više na stranici 5 dokumenta Ethical Consumer Markets Report 2015 čija je mrežna poveznica navedena u sedmoj bilješci te u popisu literature.
} 
$\mathrm{Na}$ brzu modu se dobro referira pojam McDonaldizacije kojim Ritzer (1999) načela i strategije lanaca brze prehrane drži operabilnom paradigmom zapadnog društva. Orijentirano na poboljšanja radne učinkovitosti i efikasnog plasiranja standardiziranih proizvoda za masovnu potrošnju, McDonaldizirano društvo daje primat kvantiteti, ostavljajući razorne posljedice po okolišs, poput uništavanja tla i gomilanja otpada (Ritzer, 1999:115).

Okarakteriziravši McDonaldizaciju dehumaniziranom, Ritzer (1999) smatra da veća osviještenost ljudi oko njenih neetičnih aspekata može preokrenuti ovaj, zasad dominantni, model. McDonaldizirane aspekte brzine, količine i isplativosti, uz primjenu visoke tehnologije i krajnje racionaliziran proces rada, pronalazimo i kod unosnog sustava brze mode kojoj izvanredno pristaje prefiks McFashion (Joy i sur., 2012:276) ili McDonaldizirana moda. Uz to što potiče stvaranje specifičnog modnog otpada (Pookulangara i Shepard, 2013:200), tržišni uspjeh brze mode je, baš kao i lanaca brze prehrane, neprikosnoven. Zato bi modus operandi brze mode mogao glasiti „kupi i odbaci“.

Etička protuteža brzoj modi je takozvana spora moda. Obilježava je ručni rad, unikatni motivi i dizajn, kvaliteta izrade i dugotrajnost povezani s lokalnim izvorima sirovina, smanjenim udjelom industrijske proizvodnje i ekonomskom bazom malih poduzetnika (prema Pookulangara i Shepard, 2013:201). Fraza spora moda preuzeta je od pokreta spore hrane koji je krenuo osamdesetih godina prošlog stoljeća. Radi se o protestnoj inicijativi protiv popularizacije brze prehrane. Ulažući napore u podupiranju malih farm(er)a i obrt(nik)a, pokret spore hrane ističe važnost lokalne, sezonske hrane spravljene po načelu kvalitete, a ne brzine (prema Pookulangara i Shepard, 2013:200). Sličan princip je u modnom diskursu spore mode složenom prema načelu socijalne dobrobiti i integriteta svih uključenih strana s osobitim naglaskom na radnike koji se, u usporedbi s brzom modom, znatno više vremena posvećuju izradi jednog modnog komada, što rezultira boljom kvalitetom proizvoda (prema Jung i Jin, 2016:4). U samoj izradi se koriste vlakna usklađena s ekološkim uzusima (engl. green fibers) te tehnologije i strojeve koji nisu, ili su minimalni, ekološki zagađivači. Bitno je istaknuti kako spora moda ne znači ono što sam koncept implicira - smanjenje brzine proizvodnje i s njom povezanu tržišnu neisplativost. Radi se o ujedinjenju socijalne odgovornosti, politike održivosti i poslovne transparentnosti, ali uz profitabilnost (prema Pookulangara i Shepard, 2013:200-201).

Posljednjih nekoliko godina koncept spore mode nametnuo se u raspravama o održivosti tekstilne i modne industrije u budućnosti (Pookulangara i Shepard, 2013) pri čemu je naglasak stavljen na mlade potrošače ${ }^{28}$ (Gwozdz i sur., 2013). Ipak, novija istraživanja daju ambivalentne smjernice. $S$ jedne strane pokazuju da su potrošači općenito spremni platiti više za ekološke, zelene proizvode, kao i za one proizašle iz pravedne trgovine, takozvane proizvode bez znoja (Pookulangara i Shepard, 2013:200), ali i da mladi, usprkos većoj etičkoj informiranosti u odnosu na ostatak populacije, održivost ne povezuju s modom (Joy

28 Zbog duljeg procesa obrazovanja, kasnijeg ulaska u svijet rada i sve dužeg odgađanja zasnivanja obitelji, više autora sugerira da su obrasci potrošnje stečeni u ranijoj dobi temelj potrošačkog ponašanja u narednim fazama života (prema Gwozdz i sur., 2013:16). 
i sur., 2012; Gwozdz i sur., 2013). Ovim naglašavamo kako se etički potencijal mladih potrošača nalazi u procjepu deklarativnog i praktičnog. Iako ističu da su spremni platiti više za etičku modu, ispostavlja se da njihov etički potpis ne stoji u praksi.

Forum za budućnost, civilna organizacija za promicanje održivog razvoja i njegove implementacije u korporativne i javne servise, provela je istraživanje u kojem su uključili vodeće modne stručnjake, akademike, predstavnike poslovnog svijeta, aktiviste, zakonodavce i razne analitičare s ciljem otkrivanja ključnih faktora za budućnost mode. Jedna od točaka odnosila se na prognoze razvoja etičke mode. Neki su izrazili sumnju u rast etičke mode u budućnosti. Drugi su pak optimistično ukazali na dugoročni potencijal spore mode kojom bi se modni sustav preusmjerio prema kriteriju opće kvalitete života. U tom scenariju poželjna su obnovljiva vlakna, posebno organski pamuk, metode recikliranja odjeće, globalna ekonomija sa smanjenim udjelom produkcije ugljika, ukratko, spora moda kao društvena vrijednost i poželjni životni stil..$^{29}$

Trenutna je situacija da spora moda gubi bitku s nekoliko evidentiranih barijera etičkog ponašanja koje dominiraju upravo kod njenog modnog antipoda, brze mode. To je (jeftinija) cijena, (luksuzni) imidž i modni (trendovski) izgled. Upravo te aspekte potrošači ocjenjuju važnim čimbenicima svoje modne potrošnje, uz prednost aspekta cijene (Joergens, 2006:370) koji je kod etičke mode višsstruk (Winge, 2008:519). Istraživanje Joergens (2006:366) otkriva da je potrošačima važnije osjećati se dobro u odjeći koju kupuju nego etičke posljedice modnog odabira. $\mathrm{Na}$ slične prioritete ukazuje i istraživanje Carrigan i Attalla (2001). Sve dok kemikalije koje su sadržane u odjevnim predmetima nemaju očite, negativne posljedice po njihovo zdravlje, potrošači se neće etički aktivirati u praksi. K tome su voljni zanemariti etičke prijestupe pojedinih kompanija ako im se njihova modna marka dopada. To se pokazalo u istraživanju Carrigan i Attalla (2001) te Joergens (2006) u slučaju kompanije Nike s čijim su etičkim kontroverzama potrošači upoznati, ali ih usprkos tome ne bojkotiraju. Jedno je od mogućih obrazloženja ovome po Joergens (2006:366) da sama osviještenost i informiranost ne podrazumijeva potrošačku (re)akciju. Problem nije neznanje ni medijska nepokrivenost etičkih tema, koliko nemogućnost osobnog određenja prema tim segmentima. Uz indikativan komentar Wingea (2008:512) o potrebi velike samodiscipline i posvećenosti u provedbi etičke potrošnje (i) u modnom segmentu, upitno je koliko etički model u ovom društvenom trenutku može konkurirati profitabilnoj industriji brze mode koja je pojedincima na dohvatu. Tome bi mogle pridonijeti etički zaoštrene globalne kampanje kao što je Fashion Revolution koju su 2016. promovirali modni i drugi aktivisti iz čak 92 zemlje svijeta, uključujući i Hrvatsku. Potičući modnu industriju i potrošače na preispitivanje svojih modnih navika, provociraju pitanjem tko je napravio / la moju odjeću? ${ }^{30}$ Vezano uz samu

29 Više u Levi Strauss \& Co. i Forum for the Future (2010).

30 Slično filozofiji spomenute spore mode, i ovdje se radi o holističkom pristupu koji vidi povezanost modne industrije, profita, ljudi, okoliša i kreativnosti. „Budi znatiželjan/na. Otkrij. Učini nešto. Kupnja je posljednji korak u dugom putovanju koje uključuje tisuće ljudi: nevidljivu radnu snagu iza odjeće koju nosimo. Ne znamo tko su ljudi koji izrađuju našu odjeću, pa je lako pretvarati se slijepima, ali posljedica 
Hrvatsku, etička moda prepoznata je, iz perspektive društveno odgovornog poslovanja, kao novi trend u porastu ${ }^{31}$ no ostaje za vidjeti koliko će zaživjeti u modnim vodama.

\section{ZAKLJUČAK}

Veliki etički problemi poput društvene pravde, ustvrdit će Bauman (2009), nisu u suvremenom društvu izgubili na aktualnosti. „Samo ih se treba vidjeti i tretirati na nov način“ (Bauman, 2009:10). Jedan od tih novih načina po nama je upravo etička potrošnja koju u ovom radu razumijevamo kao fenomen visoke modernosti (Giddens, 1991; Beck, 2001) ili postmodernosti (Lipovetsky, 2008; Berner i Van Tonder, 2008). Takav okvir nas upućuje na njenu fenomenološku dinamičnost (Papaoikonomou i sur., 2011) slijedom čega adresiramo kompleksnost i ambivalentnost etičke potrošnje u teoriji i praksi.

Počevši od same definicije i terminologije, etička potrošnja ne može se uopćiti. Iz raznolike literature u kojoj prevladava marketinška perspektiva, moguće je identificirati temeljne naglaske etičke potrošnje, a to su ljudska prava i radnički uvjeti, pravedna i socijalno odgovorna trgovina, održivi razvoj i zaštita okoliša, dobrobit životinja i različitih društvenih skupina te $s$ time povezane prakse, inicijative i životni stilovi (Tallontire i sur., 2001; Littler, 2011; Papaoikonomou i sur., 2011). Na osnovu toga etičkoj je potrošnji moguće pristupiti kao objedinjenoj terminologiji što u ovom radu i primjenjujemo, ili sukladno pojedinim naglascima kao što je zelena potrošnja, održiva potrošnja, socijalno odgovorna potrošnja, humana potrošnja i slično.

U domeni konceptualizacije etičkog potrošačkog ponašanja, bojkot je jedno od učestalijih (Tallontire i sur., 2001). Zbog svoje aktivističke provenijencije, sagledava se kao manifest potrošačke moći s ciljem etičke transformacije tržišnih uzusa. Varijabilni ishodi bojkota od kojih je zbog svog kontinuiteta izdvojen Nestlé, pokazuju da tržište reagira na etičke zahtjeve, ali ne bez otpora. Istodobno se s time ukazuje na problem identificiranja neetičnih kompanija što pogoduje daljnjoj netransparentnosti tržišnog sustava i predstavlja barijeru etičkim potrošačkim izborima. Za istaknuti je kako problematika bojkota odražava postojeće odnose moći koji se, ako se poslužimo Castellsovom (2002) terminologijom, odvijaju između legitimirajućih identiteta koje prepoznajemo u tržišsnim kompanijama te identiteta (iz) otpora za čiji primjer uzimamo etičke grupacije. Iz ovog je očito da etički bojkoti (su)proizvode (re)akcije, jednako kao što su i sami uvjetovani društvenim i tržišnim odnosima.

toga su milijuni ljudi koji pate, čak i umiru“. Više na mrežnoj stranici službene inicijative Fashion Revolution čija je mrežna poveznica navedena u prvoj bilješci i u popisu literature te na mrežnoj stranici hrvatske podružnice inicijative We Are Fashion Revolution Croatia (2016).

31 Radi se o tri hrvatska dizajna izdvojena po svom održivom i etičkom standardu u konceptu i izvedbi. To je dizajn Hollywood glasses kojim za svaki kupljeni primjerak naočala posadi novo stablo u ime održivosti i ekološke ravnoteže. Drugi je dizajn Mandali Mendrilla koji koristi prirodne materijale iz ekološkog uzgoja i ekološke boje za tkaninu koje ne uključuju ubijanje životinja. Treći je dizajn Druid s ponudom ručno izrađenih proizvoda od prirodnih i recikliranih materijala. Više na mrežnoj stranici Instituta za društveno odgovorno poslovanje u prilogu Održiva moda (IDOP, 2016) 
Istaknuvši problem individualizacije odgovornosti kojom se etička potrošnja prebacuje na razinu pojedinca, a što prema nekima minorizira uloga vlada, država i kompanija, pojedini autori sugeriraju veće etičke inicijative $s$ vrha. Smatrajući kako su takva rješenja promašena jer je trend suvremenih društvenih događanja okrenut kulturi pojedinaca koji kreativno rješava tekuće probleme, ali je istodobno „bombardiran kontradiktornim moralnim zapovijedima, opcijama i težnjama, $s$ teretom odgovornosti za svoje činove na leđima", Bauman (2009:43) u isti mah detektira probleme iz svakodnevice etičkih potrošača. Pojedina istraživanja pokazuju kako oni osjećaju dužnost etičkog djelovanja, mada ih u svakodnevici ne uspijevaju cjelovito i sustavno realizirati (Connolly i Prothero, 2008; Tallontire i sur., 2001). Rezultat je disperziranost etičkih profila prema različitim shvaćanjima vlastite uloge naspram konteksta potrošačke kulture, učestalosti provođenja etičkih praksa, odabiru etičke domene i tako dalje. Na osnovu toga upućene su kritike etičkim potrošačima dovodeći ih u vezu s brigom za vlastitu biografiju u čemu prednjači orijentiranost na osobno zdravlje i tijelo, a tek sekundarno na društvenu dobrobit. Kako su pojedina istraživanja pokazala (Shaw i sur., 2005; Tallontire i sur., 2001), kod etičkih potrošača simultano egzistiraju vrijednosti usmjerene na vlastito i društveno dobro, dakle, radi se o uključivom modelu. Slijedom navedenog, u ovom se radu etičke potrošače sagledava u kontekstu višestrukih identiteta i simultanih vrijednosti pri čemu podcrtavamo vlastiti stav da etički potrošači nisu uniformna kategorija. Time se vraćamo na uvodni argument kako je etička potrošnja razumljiva kroz kompleksne i često kontradiktorne sastavnice.

Imajući u vidu trend rasta etičke potrošnje zadnjih godina, smatramo da tema zaslužuje veću pozornost domaće struke, napose sociologije. $S$ obzirom da se etička potrošnja može sagledati kao luksuzni fenomen vezan uz postindustrijske zemlje, jedna od problematizacija mogla bi se usmjeriti na perspektivnost etičke potrošnje u sociokulturnom kontekstu Hrvatske. Kako je u ovom radu poseban fokus na etičkoj modi, relevantno bi bilo produbiti njen potencijal za domaću tekstilnu i modnu industriju, tim više jer su napravljeni određeni koraci u tom smjeru.

Zaključno želimo istaknuti kako ovim radom istaknute ambivalencije etičke potrošnje po nama ne govore o njenoj slabosti, koliko o društvenoj konotiranosti, čemu bi u perspektivi budućih studija mogao doskočiti interdisciplinarni znanstveni pristup.

\section{LITERATURA}

Arnold, C. (2009). Ethical Marketing and the New Consumer. West Sussex: John Wileyand Sons.

Baby Milk Action. (2014). Why boycott Nestlé Fair trade KitKat? URL: http://archive. babymilkaction.org/pdfs/factsfairtrade0514.pdf (27.10.2016.)

Baby Milk Action. (2016). Nestlé and the Fair trade mark. URL: http://www.babymilkaction.org/nestle-fairtrade (27.10.2016.)

Bauman, Z. (2009). Postmoderna etika. Zagreb: AGM.

Beck, U. (2001). Rizično društvo. Ususret novoj moderni. Beograd: Biblioteka Eunomia. 
Belk, R. W., Devinney, T. i Eckhardt, G. (2005). Consumer ethics across cultures. Consumption Markets \& Culture, 8(3): 275-289.

Berner, A. i Van Tonder, C. L. (2003). The postmodern consumer: implications of changing customer expectations for organisation development in service organisations. Journal of Industrial Psychology, 29(3): 1-10.

Bocock, A., Dresler-Hawke, E. i Mansvelt, J. (2007). Ethical consumption: exploring purchase rationales and choices. URL: http://anzmac.org/conference_archive/2007/ papers/E\%20Dresler-Hawke_1a.pdf (01.11.2016.)

Burke, J. i Hammadi, S. (2012). Bangladesh textile factory fire leaves more than 100 dead. The guardian. URL: http://www.theguardian.com/world/2012/nov/25/bangladesh-textile-factory-fire (27.10.2016.).

Carrigan, M. i Attalla, A. (2001). The myth of the ethical consumer - do ethics matter in purchase behaviour. Journal of Consumer Marketing, 18(7): 560-578.

Caruana, R. (2007). A sociological perspective of consumption morality. Journal of Consumer Behavior, 6(5): 287-304.

Castells, M. (2000). Uspon umreženog društva. Informacijsko doba: Ekonomija, društvo i kultura. Svezak I. Zagreb: Golden marketing.

Castells, M. (2002). Moć identiteta. Informacijsko doba. Ekonomija, društvo i kultura. Svezak II. Zagreb: Golden marketing.

Clean Clothes Campaign. (2013). Bangladesh Minimum Wage. URL: http://www.cleanclothes.org/livingwage/bangladesh-minimum-wage (27.10.2016.)

Clean Clothes Campaign. (2015). Global actions targeting Benetton and Mango in Rana Plaza aftermath. URL:https:/cleanclothes.org/news/press-releases/2015/04/17/global-actions-targeting-benetton-and-mango-in-rana-plaza-aftermath (27.10.2016.)

Clean Clothes Campaign. (2016a). Safety. Ali Enterprises: A Factory Inferno. URL: http://www.cleanclothes.org/safety/ali-enterprises (27.10.2016.)

Clean Clothes Campaign. (2016b). Safety. Rana Plaza. URL: https://cleanclothes.org/ safety/ranaplaza (27.10.2016.)

Clean Clothes Campaign, International Labor Rights Forum, Maquila Solidarity Network i Worker Rights Consortium. (2016). Ongoing Safety Delays at H\&M Suppliers in Bangladesh. Memo. URL: http://www.cleanclothes.org/resources/publications/ongoing-safety-delays-at-h-m-suppliers-in-bangladesh (27.10.2016.)

Coletto, D. (2011). Ethical Consumerisam and Canadians. Part 2 of the Corporate and Community Social Responsibility (CCSR) Research Series. Izlaganje na CCSR konferenciji. URL: http://abacusdata.ca/wp-content/uploads/2011/01/CCSR-Ethical-ConsumerismFinal.pdf (27.10.2016.).

Connolly, J. i Prothero, A. (2008). Green consumption: Life-politics, risk and contradictions. Journal of Consumer Culture, 8(1): 117-147.

Cruelty-Free Kitty. (2017). How L'Oreal is Misleading Customers About Being Cruelty-Free. URL: http://www.crueltyfreekitty.com/news/loreal-animal-testing-notcruelty-free/\#YlttT6qbxvVeosAc.99 (27.10.2016.) 
Dolan, C. S. (2005). Fields of Obligation. Rooting ethical sourcing in Kenyan horticulture. Journal of Consumer Culture, 5(3): 365-389.

Giddens, A. (1991). Modernity and Self-Identity. Cambridge: Polity Press.

Gwozdz, W., Netter, S., Bjartmarz, T. i Reisch, L. A. (2013). Report on Survey Results on Fashion Consumption and Sustainability among Young Swedes. Mistra Future Fashion Report. Copenhagen: Copenhagen Business School.

H\&M Group. (2016). Sustainability. URL: http://about.hm.com/en/sustainability. html (27.10.2016.)

Institut za društveno odgovorno poslovanje (IDOP). (2016). Održiva moda. URL: http:// www.idop.hr/hr/dop-trendovi/dop-u-hrvatskoj/odrziva-moda/ (27.10.2016.)

Joergens, C. (2006). Ethical fashion: myth or future trend? Journal of Fashion Marketing and Management, 10(3): 360-371.

Joy, A., Sherry, J. F., Venkatesh, Jr. A., Wang, J. i Chan, R. (2012). Fast fashion, sustainability, and the ethical appeal of luxury brands. Fashion Theory, 16(3): 273-296.

Jung, S. i Jin, B. (2016). Sustainable Development of Slow Fashion Businesses: Customer Value Approach. Sustainability, 8(6):540, DOI:10.3390/su8060540.

KiK Textilien und Non-Food GmbH. (2015). Factory Fire Ali Enterprises: KiK rejects accusations of international trade unions. Press release. URL: http://businesshumanrights.org/sites/default/files/documents/2015_09_10_PR_Factory\%20 Fire\%20Ali\%20Enterprises_KiK\%20rejects\%20accusations\%20of\%20international\%20trade\%20unions.docx (27.10.2016.)

Lipovetsky, G. (2008). Paradoksalna sré́a. Ogled o hiperpotrošačkom društvu. Zagreb: Biblioteka Antibarbarius.

Littler, J. (2011). What's wrong with ethical consumption? U: Lewis, T. i Potter, E. (ur.), Ethical Consumption: A Critical Introduction (str. 27-39). Abingdon: Routledge.

Lekakis, E. J. (2013). Coffee Activism and the and the Politics of Fair Trade and Ethical Consumption in the Global North. Political Consumerism and Cultural Citizenship. Basingstok: Palgrave Macmillan.

Levi Strauss \& Co. i Forum for the Future. (2010). Fashion futures 2025: global scenarios for a sustainable fashion industry. URL: https:/www.forumforthefuture.org/sites/default/files/project/downloads/fashionfutures2025finalsml.pdf (01.11.2016.)

L'Oréal Group. (2016a). Innovating. URL: http://www.sharingbeautywithall.com/en/ innovating (27.10.2016.).

L'Oréal Group. (2016b). Sustainability. Frequently asked questions. URL: http://www. loreal.com/sustainability/l'or\%C3\%A9al-answers/the-question-of animaltesting/ frequently-asked-questions (27.10.2016.)

McEachern, M. G. i Carrigan, M. (2010). Consuming ethically? Exploring the dilemmas facing ethical consumers. U: Solomon, M. R., Bamossy, G., Askegaard, S. i Hogg, M. K. (ur.), Consumer Behaviour: A European Perspective (str. 229-231). London: Financial Times / Prentice Hall.

Micheletti, M. (2003). Political virtue and shopping. Individuals, consumerism, and collective action. New York: Palgrave Macmillan. 
Morgan, C. J., Croney, C. C. i Widmar, N. J. O. (2016). Exploring Relationships between Ethical Consumption, Lifestyle Choices, and Social Responsibility. Advances in Applied Sociology, 6(5): 199-216.

Muldoon, A. (2006). Where the green is: examining the paradox of environmentally conscious consumption. Electronic Green Journal, 1(23). URL: http://escholarship. org/uc/item/00t326gx (01.05.2016.)

Papaoikonomou, E., Ryan, G. i Valverde, M. (2011). Mapping ethical consumerbehavior: integrating the empirical research and identifying future directions. Ethic \& Behavior, 21(3): 197-221.

People for the Ethical Treatment of Animals (PETA). (2016). L'Oréal used to be included on the cruelty-free list. Now I see that it is included on the „do test" list. What happened? URL: http://www.peta.org/about-peta/faq/loreal-used-to-be-includedon-the-cruelty-free-list-now-i-see-that-it-is-included-on-the-do-test-list-what-happened/ (27.10.2016.)

Pookulangara, S. i Shephard, A. (2013). Slow fashion movement: Understanding consumer perceptions - An exploratory study. Journal of Retailing and Consumer Services, 20(2): 200-206.

Ritzer, G. (1999). McDonaldizacija društva. Zagreb: Jesenski i Turk.

Shaw, D., Grehan, E., Shiu, E., Hassan, L. i Thomson, J. (2005). An exploration of values in ethical consumer decision making. Journal of Consumer Behaviour, 4(3): 185-200.

Smith, N. C. (2003). Corporate social responsibility: whether or how? California Management Review, 45(4): 52-76.

Soneryd, L. i Uggla, Y. (2015). Green governmentality and responsibilization: new forms of governance and responses to „consumer responsibility“. Environmental Politics, 24(6): 913-931.

Spaargaren, G. (2003). Sustainable Consumption: A Theoretical and Environmental Policy Perspective. Society and Natural Resources, 16(8): 687-701.

Spaargaren, G. i Mol, P. J. (2008). Greening global consumption: Redefining politics and authority. Global Environmental Change, 18(3): 350-359.

Tallontire, A., Rentsendorj, E. i Blowfield, M. (2001). Ethical consumers and ethical trade: a review of current literature. Natural Resources Institute Policy Series 12. London: University of Greenwich.

The fashion revolution (2016). URL: http://fashionrevolution.org/ (27.10.2016.)

Triodos Bank i Ethical consumer. (2015). The Ethical Consumer Markets Report 2015. URL: http://www.ethicalconsumer.org/portals/0/downloads/ethical\%20consumer\%20markets\%20report\%202015\%20final.pdf (27.10.2016.).

The true cost. (2015). The true cost movie. URL: http://truecostmovie.com/ (27.10. 2016.) Winge, T. M. (2008). „Green is the new black“: Celebrity and the „Green" Commodity Fetish. Fashion Theory, 12(4): 511-523.

We Are Fashion Revolution Croatia. (2016). URL: http://fashionrevolution.org/country/croatia/ (27.10.2016.). 


\title{
THE ISSUE OF ETHICAL CONSUMPTION FROM THE SOCIAL PERSPECTIVE
}

\author{
Ivana Brstilo, Ines Krešić and Karla Vučković
}

\begin{abstract}
The purpose of this paper is a sociological discussion of ethical consumption, which recently came into focus due to a series of accidents in textile and fashion industries in the, so called, developing countries. In the introduction, we examine multiple meanings of the term ethical consumption and analyse the results of relevant research, in order to address the existence of heterogeneous categories of ethical consumers, as well as formulate our main thesis on the complexity of ethical consumption in both theory and practice. Using the example of ethical consumer boycotts, we show that they result in diverse strategies employed by the companies and corporations. This way ethical consumption becomes part of a network of multiple interested actors and one of the goods on the market. Particular focus of this paper is placed on the fashion industry, where we observe the contradictions between ethical or "slow" fashion and dominant trends of "fast" fashion, which raises the question about the possibilities of mass implementation of ethical fashion into contemporary textile and fashion scene. In this paper, ethical consumption is seen as an ambivalent phenomenon of high modernity and postmodernity, as debated by a number of contemporary sociological authors. In the conclusion, we additionally point to the necessity of further research of this emergent phenomenon within the specific sociocultural context of Croatia.
\end{abstract}

Keywords: ethical consumption, ethical consumers, ethical consumer boycott, slow fashion, postmodernity

\section{ÜBER STREITIGKEITEN DES ETHISCHEN KONSUMS AUS DER SOZIALEN PERSPEKTIVE}

\author{
Ivana Brstilo, Ines Krešić und Karla Vučković
}

\section{Zusammenfassung}

Das Ziel dieser Arbeit ist die soziologische Problematisierung des ethischen Konsums, der neulich im Brennpunkt steht, nachdem es zu einer Reihe von Unfällen in den Textilbetrieben der sogenannten Entwicklungsländer gekommen ist. In der Einleitung wird die terminologische Mehrdeutigkeit erörtert und relevante Forschungsresultate werden analysiert, um auf das Bestehen von heterogenen Kategorien ethischer Konsumenten hinzuweisen; auf Grund dessen wird die These über die Komplexität des ethischen Konsums in Theorie und Praxis formuliert. An Beispielen des ethisch motivierten Konsumentenboykotts zeigen wir, wie deshalb verschiedenartige Strategien von Firmen entstehen. Dies bringt den ethischen Konsum ins Netz mehrerer Interessenakteuren und positioniert ihn zugleich als eine der Marktinstanzen. In der Arbeit wird ein besonderes Augenmerk auf die Modeindustrie gerichtet, wobei wir die Opposition zwischen der ethischen oder langsamen Mode und der dominierenden Trends der schnellen Mode merken, was ihre baldige Massenverwendung in der heutigen Mode- und Textilindustrie in Frage stellt. Ethischer Konsum wird in dieser Arbeit als ein ambivalentes Phänomen der hohen Modernität oder Postmodernität betrachtet, über das man auf Grund einer Reihe von Arbeiten zeitgenössischer soziologischer Autoren diskutieren kann. Schließlich weisen wir auf den Bedarf der weiteren Erforschung dieses wachsenden Phänomens im soziokulturellen Kontext Kroatiens hin.

Schlüsselwörter: ethischer Konsum, ethische Konsumenten, ethisch motivierter Konsumentenboykott, langsame Mode, Postmoderne 